\title{
DIETARY BEHAVIOUR OF STUDENTS FROM POZNAN UNIVERSITIES
}

\author{
IDA LAUDANSKA-KRZEMINSKA \\ Department of Health Education, \\ University School of Physical Education, Poland
}

\begin{abstract}
The problem raised in the study relates to the eating habits of students and their relations with the body mass index (BMI). The effect of selected sociodemographic variables (sex, place of residence, material status, field of study) on eating habits of the respondents was also analysed. The structure of the Dietary Behaviour Index (DBI) was proposed and its relations to the BMI were established.
\end{abstract}

Material and methods. The study covered 508 students of state and private universities in Poznań (Poland) of whom 73\% were female and 27\% male. The study used an anonymous questionnaire poll on the basic dietary habits developed on the basis of the Food Pyramid guidelines as well as the Golden Charter of Correct Nutrition. The BMI was calculated on the students' self-reported weight and height.

Results. $15 \%$ of the participating students are overweight or obese. The distribution of the BMI differs between men and women $(\mathrm{p}<.000)$. Particularly unfavourable behaviour was noted in terms of the consumption of legumes (72\% of respondents), fish (53\%), dairy products (36\%), vegetables (29\%) and fruit $(27 \%)$. Beneficial trends relate to the everyday consumption of breakfast (63\%), the number of meals per day (59\%), limiting the consumption of red meat (59\%), including vegetable fats in the daily diet (56\%). The differences in the way of eating described by the DBI is related to the field of study $(\mathrm{p}<.001)$ as physical education students had the best indicators.

Conclusions. In the studied group of students overweight and obesity are not as frequent as in other countries of Western Europe or America. We noted a number of dietary mistakes made by the respondents, which can lead to adverse health consequences in the future. During the university studies, not 
only in the fields related to health, information promoting pro-health lifestyle should appear more often.

Key words: dietary behaviour, eating patterns, students, Poland, BMI

\section{INTRODUCTION}

Dietary behaviour is one of the most significant risk factors of civilisationrelated diseases [12]. The health effects of dietary mistakes such as cancers, type 2 diabetes, hypertension or obesity do not appear immediately, thus it is particularly important to monitor the dietary behaviour of young people $[3,5$, 10]. A person, also a young person, faces the need to reconcile health recommendations of specialists on the one hand, and his or her own culinary preferences on the other hand. Unfortunately, often it is not easy and a careful search for a compromise is needed. A correct diet involves following many various recommendations and their relations to health and disease are the subjects of numerous scientific reports $[7,18,19]$.

From the point of view of public health it is important to formulate relatively easy dietary tips and recommendations, which are also simple to communicate. The best known and popular dietary guidelines for healthy adults are presented in the so-called food pyramids [2, 21]. In Poland we also refer to the document called the Golden Charter of Correct Nutrition signed by several dozens of medical organisations involved in the promotion of appropriate nutrition of sick people, people at a risk of diseases and healthy people [23]. As we know, dietary recommendations evolved in the last few decades, therefore many people oppose the new, better guidelines from specialists, in order to justify their own bad eating habits. At the same time, it is not often that we encounter a person who follows a completely healthy diet. Therefore, attempts are made to indicate the recommendations which are most important for health and to categorise the behaviour of respondents indicating whether the presented diet is beneficial for health or not. The current study joins this discussion.

The study raises the problem of dietary habits of students of Poznan universities and the relation of these habits to the Body Mass Index (BMI). An attempt was also made to categorise the diets of students on the basis of the analysed dietary behaviour. The following questions were asked in this report: Do students in the city of Poznan follow the healthy dietary style and to what extent? Is it related to socio-demographic variables which characterise the 
respondents? What are the most common dietary mistakes? What is the least difficult in terms of the diet of the respondents? Is healthy eating related to a better body mass index of the respondents?

\section{MATERIAL AND METHODS}

The study used the method of a diagnostic survey and the technique of anonymous questionnaire poll. The results are a part of a wider study of healthrelated behaviour of the student population of the Wielkopolska Province in Poland. The study was carried out in April and May 2011. The study included 508 students from Poznan state universities (University School of Physical Education, Adam Mickiewicz University, Poznan University of Technology, Medical University) and private universities (the Academy of Hotel Management and Catering Industry, Wielkopolska Higher School of Tourism and Management, Poznan Trade and Commerce College). The stratification of the respondents was presented in Table 1.

Table 1. Socio-demographic status of the studied group of respondents

\begin{tabular}{lcc} 
& Number (n) & Percentage (\%) \\
\hline Women & 372 & 73 \\
\hline Men & 136 & 24 \\
\hline Full-Time Students & 396 & 78 \\
\hline Extramural Students & 112 & 22 \\
\hline Living With Parents & 240 & 47 \\
\hline Living With Their Own Family & 36 & 7 \\
\hline Living On Their Own & 232 & 46 \\
\hline Material Status: Low & 16 & 3 \\
\hline Material Status: Average & 170 & 34 \\
\hline Material Status: Good & 271 & 53 \\
\hline Material Status: Very Good & 51 & 10
\end{tabular}

The questionnaire used in the study contained 12 questions about strategic habits making up the pattern of dietary behaviour. The questions related to: the frequency of meals, eating breakfast daily and the frequency of eating selected foods, important for health (wholegrain products, vegetables, fruit, milk and dairy products, legumes, red meat, poultry, fish, vegetable fats, water and natural juices). The responses were classified into three groups according to 
the guidelines of the Food Pyramid and the Golden Charter of Correct Nutrition: positive ( 3 points), moderate ( 2 points), negative ( 1 point). Then the classification of the diet pattern of the participating students was made depending on the number of the points scored (the minimal number of points 12 - all the habits negative, and the maximum number 36 - all the habits positive). The reference point was the arithmetic mean of 12 questions. If it was less then a 2 points, such a diet model was considered negative, from 2 to 2.5 - it was moderate, and 2.5 or more - positive.

The study also used the body mass index (BMI) calculated on the students' self-reported weight and height. The classification used was based on the WHO recommendations [14].

The statistical analyses were carried out with Statistica (Version 9) software using non-parametric Mann-Whitney and Kruskal-Wallis tests; also the Spearman's rank correlation and the tau Kendalla correlation were calculated and percentages were calculated.

\section{RESULTS}

In the studied group of respondents the problem of obesity and overweight applies to approx. $15 \%$ of the people. Table 2 presents the frequency of occurrence of individual BMI categories in the studied group of students. Women are significantly more often underweight $(\mathrm{p}<.000)$ than men $(13 \%$ of female respondents compared to $0 \%$ of men). Out of the analyzed socio-demographic variables, describing the respondents, only the current place of residence differentiates the status of nutrition of the subjects $(\mathrm{p}<.01)$. Problems with obesity or overweight are more frequent in the students who have started their own families. Living with one's parents or on one's own resources in a rented room or in the students' dormitory has a kind of protective property in this respect. The material status of respondents, parents' education and the field of study were not related to the differences in terms of incorrect values of the BMI in the subjects. 
Table 2. The BMI and the sex of the respondents

\begin{tabular}{lccccccccc} 
& \multicolumn{8}{c}{ BMI categories } \\
& \multicolumn{2}{c}{$\begin{array}{c}\text { Underweight } \\
(<18.5)\end{array}$} & \multicolumn{2}{c}{$\begin{array}{c}\text { Normal } \\
(18.5-24,9)\end{array}$} & \multicolumn{2}{c}{$\begin{array}{c}\text { Overweight } \\
(25-29.9)\end{array}$} & obese $(\geq 30)$ \\
\cline { 2 - 10 } & $\mathrm{n}$ & $\%$ & $\mathrm{n}$ & $\%$ & $\mathrm{n}$ & $\%$ & $\mathrm{n}$ & $\%$ \\
\hline Women & 48 & 14 & 264 & 75 & 29 & 8 & 13 & 4 \\
\hline Men & - & - & 101 & 75 & 26 & 20 & 7 & 5 \\
\hline All & 48 & 10 & 365 & 75 & 55 & 11 & 20 & 4 \\
\hline
\end{tabular}

In the present study 12 dietary habits were analyzed. The respondents were asked to indicate the number of meals they have per day, as well as provide information on how often they eat breakfast and the frequency of eating the foods important for the health: wholegrain products, vegetables, fruit, milk and dairy products, red meat, poultry, fish, vegetable fats, legumes, water and natural juices. Figure 1 shows how often the students eat breakfast depending on the sex and the BMI of the respondents.

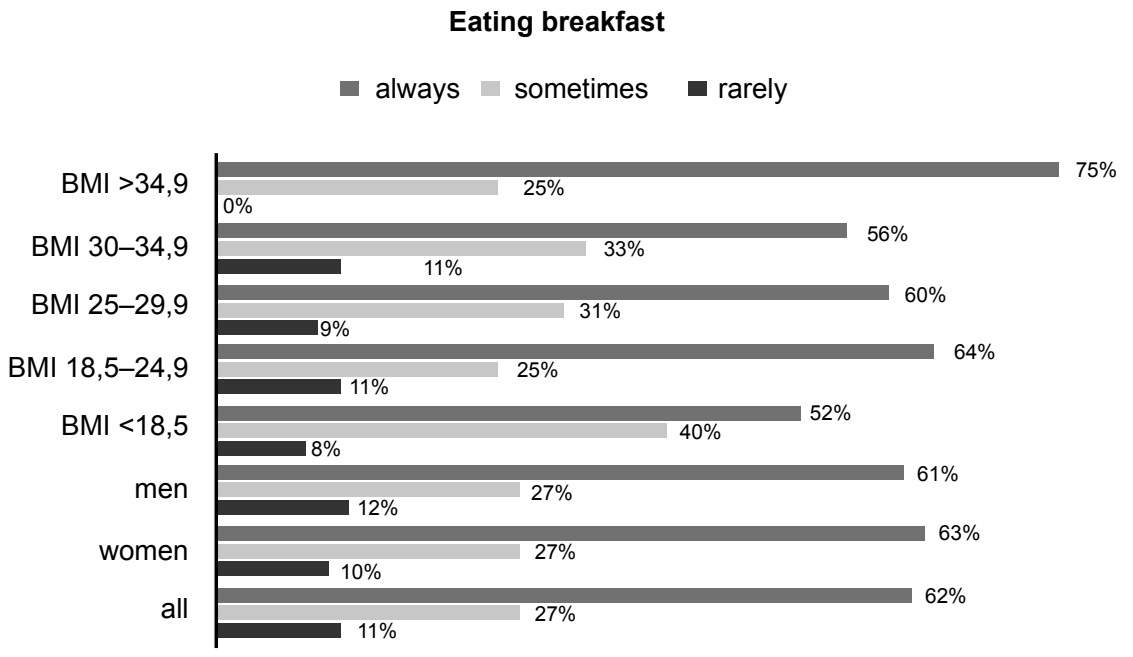

Figure 1. The frequency of eating breakfast by respondents depending on their sex and the BMI (\%)

The majority of the students usually eat breakfast and no statistically significant differences were noted between men and women. The BMI also is not differentiated by this selected habit. 
Figure 2 presents the number of meals consumed by the respondents depending on the sex and the BMI.

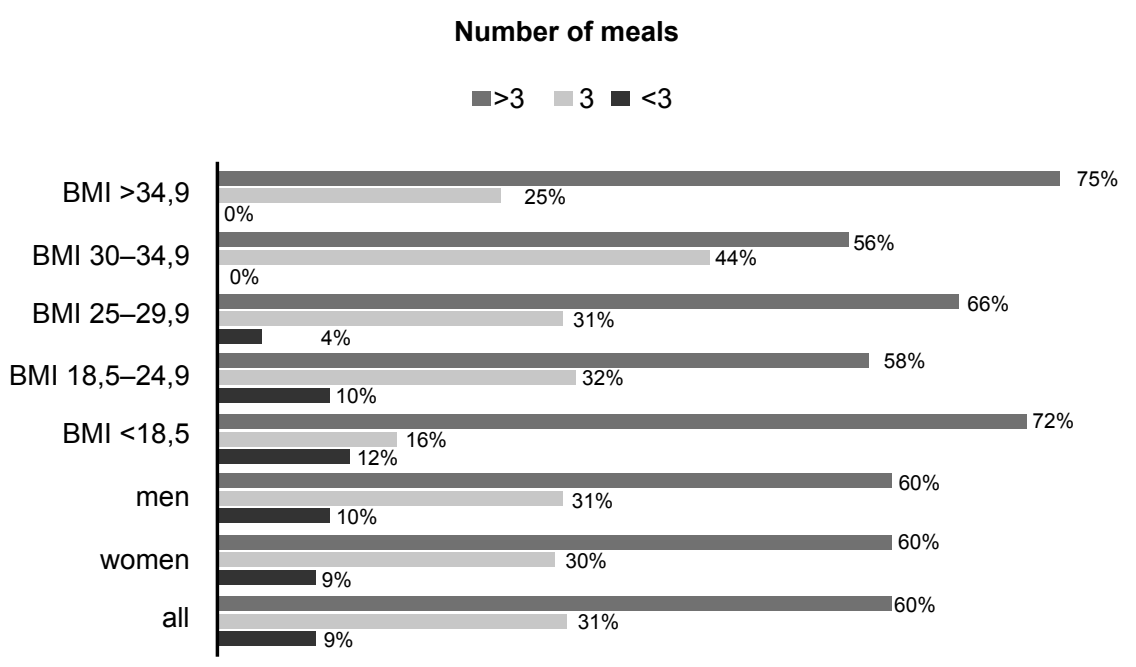

Figure 2. Number of meals consumed by students per day depending on the sex and the BMI (\%)

The majority of students eat, as recommended, more than three meals a day. No difference was noted between men and women in this respect. What is interesting, underweight students $(\mathrm{BMI}<18.5)$ most often represent the most beneficial behaviour (more than three meals) and the least beneficial behaviour (less than three meals a day).

Figure 3 shows the percentages of the respondents who consume certain foods with certain frequency.

Let us follow the consumption of individual foods and their relations with the BMI and individual socio-demographic variables (Table 3). Less than half of the participants eat daily wholegrain products such as bread, rolls and pasta. They still do not constitute the basis of the students' diets, in spite of generally available knowledge and many advertising campaigns about it. Everyday consumption of fruit and vegetables (including frozen fruit and vegetables) looks even worse. Approximately $30 \%$ of respondents eat them every day, and only some $(1-3 \%)$ a few times a day. Women eat fruit slightly more often $(p<.05)$. As it turns out, the current place of residence has a great impact on the amount of fruit consumed by young people $(\mathrm{p}<.01)$, the most being eaten by 


\section{Food consumption}

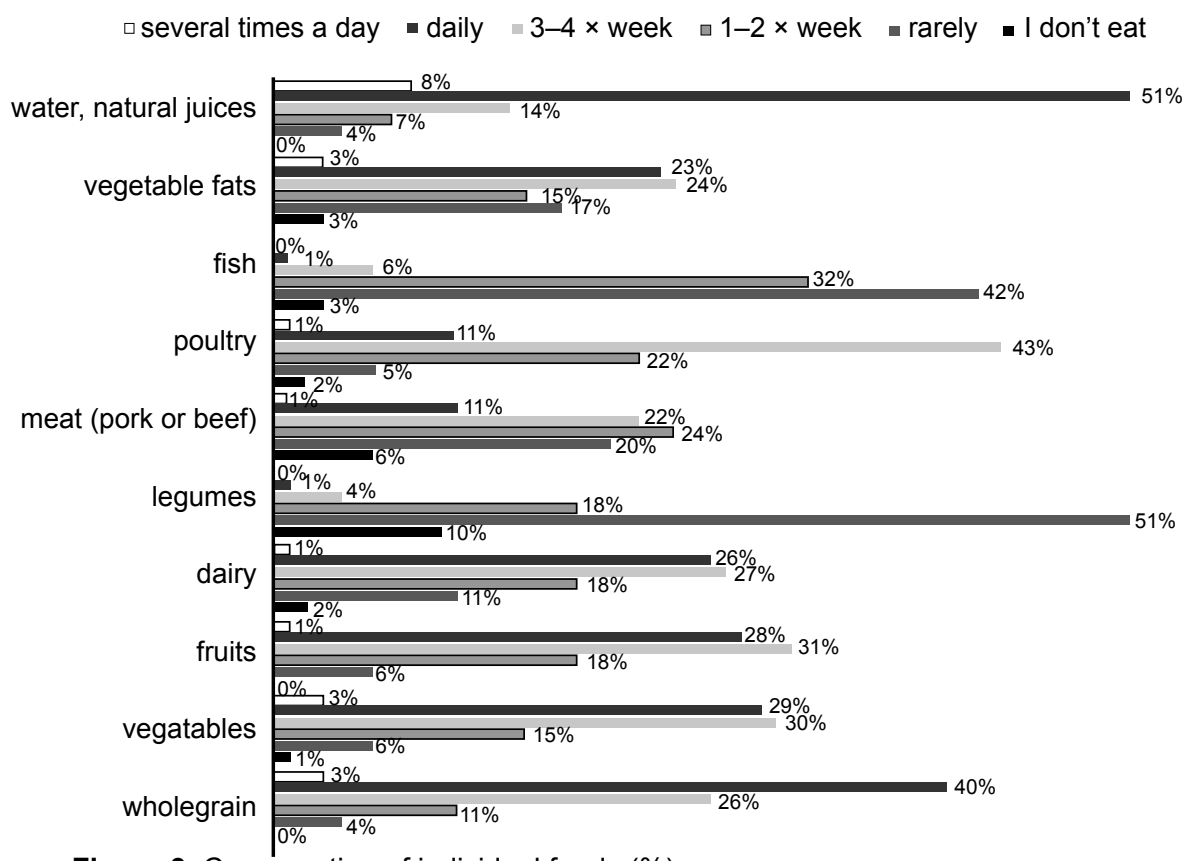

Figure 3. Consumption of individual foods (\%)

those living with their own family, much less by those living with their parents, and the least by those living on their own in a students' dormitory or in a rented room - as it seems they would be most independent of their families. The consumption of fruit is also related to the field of study of the participants $(\mathrm{p}<.01)$. Physical education students eat most fruit, followed by medical students. The cosmetology students eat fruit least often. The majority of the respondents do not follow the dietary recommendations which probably will have a great impact on the health of future elites. The consumption of dairy products (milk, cheese, yoghurt) is similar. Less than $30 \%$ of the subjects follow the recommendations to eat them every day. The majority of subjects, as it seems, already at their young age contribute to many health consequences resulting from an insufficient supply of calcium and other important nutrients contained in dairy products (e.g. protein in the form of low-calorie dairy products). We also notice the effect of the field of study on the rationalisation of students' diets in this respect $(\mathrm{p}<.001)$. Again, it is physical education students who most often follow the recommendations, followed by social science students. Medicine students eat dairy products least often. The questioned students also avoid eating vegetable sources of proteins such as 
legumes (e.g. soy, beans, peas). Most of them eat them seldom or never, and men eat them slightly more often $(\mathrm{p}<.05)$. Similarly, students of various fields of study differ in their preferences in this respect $(\mathrm{p}<.001)$. Social science and medical students eat legumes least often. As we know, legumes should be eaten as a substitute of animal sources of protein, in particular fat rich meats, once or twice a week. The data indicate that this is not a general practice among students.

Fish consumption is slightly better. Approximately $40 \%$ of respondents eat fish once or twice a week or more often. This is still an insufficient percentage, in particular taking into account many advertising campaigns in Poland and a tradition of many generations, which involves having meat-free meals, often fish meals, every Friday. Students of tourism and recreation and cosmetology students eat fish least often $(\mathrm{p}<.01)$. In terms of meat consumption we noted that poultry is on the menu more often than red mead (pork, beef). This is a beneficial and welcome direction of changes. We noted a more frequent consumption of red meat by male students as compared to female students $(\mathrm{p}<.001)$. Water and natural juices are in the daily diet of the majority of the subjects, but significantly more often in men's diets $(\mathrm{p}<.001)$ and least often in diets of the students of social sciences $(\mathrm{p}<.01)$. Unfortunately, vegetable fats are not a popular addition to everyday diet.

In the current study 12 dietary habits were analyzed. The study described also correlations (the Spearman's rank correlation or the Kendall's tau) of the DBI with certain dietary habits which it is made up of (Table 3). The correlations ranged from 0.07 to 0.61 . The correlation of red meat and poultry consumption with the indicator was the lowest.

In the next stage of analysis an attempt was made to classify the diets of students taking into account the 12 habits above. This was done on the basis of the value of the arithmetic mean. Three categories of dietary behaviour patterns were obtained: negative, moderate, positive. Taking into account the number of statistically significant relations between individual habits making up the DBI and the BMI and socio-demographic variables (Table 3), it was expected that only statistically significant differences for the DBI in respect of the field of study of the respondents will be obtained. Such a relation was obtained $(\mathrm{p}<.001)$. According to the DBI $-22 \%$ of respondents present negative eating habits, $55 \%$ - moderate and $23 \%$ of them - positive habits. 
Table 3. Significance of the relations of the studied dietary habits with sex, the BMI and the socio-demographic situation (the Mann-Whitney test or the Kruskal-Wallis test)

\begin{tabular}{|c|c|c|c|c|c|}
\hline & \multicolumn{4}{|c|}{$\mathrm{p}$-value } & \multirow{2}{*}{$\frac{r}{D B I}$} \\
\hline & Sex & BMI & $\begin{array}{l}\text { Place of } \\
\text { residence }\end{array}$ & $\begin{array}{l}\text { Field of } \\
\text { study }\end{array}$ & \\
\hline Number of meals & ,94 &, 541 &, 061 &, 001 &, $29^{* * *}$ \\
\hline Frequency of eating breakfast & ,860 & ,882 & , 195 & ,016 &, $38^{* \star *}$ \\
\hline Wholegrain products & ,661 & ,441 & ,904 & ,72 &, $39^{* * *}$ \\
\hline Vegetables & ,383 &, 061 & 411 & ,156 & $61^{* \star *}$ \\
\hline Fruit &, 027 & ,482 & ,022 & ,003 &, $52^{* * *}$ \\
\hline Dairy products & ,252 &, 115 & ,818 & ,001 &, $42^{\star \star *}$ \\
\hline Legumes &, 012 & ,705 &, 78 &, 001 &, $45^{\star \star \star}$ \\
\hline Red meat &, 000 & ,212 & ,261 & ,098 &, $12^{\star *}$ \\
\hline Poultry & .023 & ,020 &, 587 & ,528 &, $08\left(, 07^{*}\right)$ \\
\hline Fish & ,461 &, 077 & ,458 & ,012 & $41^{* \star *}$ \\
\hline Vegetable fats & , 164 & ,869 & ,628 & ,337 &, $28^{* * *}$ \\
\hline Water and natural juices & ,001 &, 505 & ,039 & ,001 &, $36^{* \star *}$ \\
\hline
\end{tabular}

$p$ - value - bold $p<.05$;

$\mathrm{r}$ - Spearman rank correlation or Kendall's tau correlation

${ }^{*}-p<.05 ;{ }^{* *}-p<.001 ;{ }^{* * *} p<.001$

\section{DISCUSSION}

Dietary habits of the questioned students were analysed both from the point of view of the frequency of consumption of individual products and in terms of generalisation in the form of the DBI. The assessment of basic dietary habits of students showed both positive trends and a number of mistakes. The assessment of the nutrition using the Body Mass Index showed a large percentage of people with incorrect weight - $15 \%$ above the normal weight and $10 \%$ below the normal weight. These indicators are lower than those noted for American students, where approx. 35\% of respondents are overweight or obese [17] or students from Croatia $-23 \%$ [4].

The majority of respondents follow the recommendations relating to an optimum number of meals per day. Similarly, in an all-Poland survey carried out by the CBOS (Public Opinion Research Centre) positive habits of Poles in this respect have been noted for more than 10 years $[13,22]$. Similarly, the majority of students of a medical university and a physical education university in the study of Duda, consume three or more meals a day [6]. Eighty percent of people declared eating breakfast every day in an all-Poland survey. In the 
studied group of students this important element is present in the daily routine of $62 \%$ of respondents. Students often have an irregular cycle of work (study) and rest, which does not favour the regularity of eating meals and may also affect such differences in comparison to the population in general.

One of the more important dietary mistakes made by the studied students is infrequent eating of fruit and vegetables. Only $37 \%$ of adult Poles eat vegetables every day and in the studied group only $32 \%$ of respondents do it. Everyday consumption of fruit is even lower (less than $30 \%$ of the studied students). As the surveys of CBOS show, the falling trend in the consumption of fruit and vegetables has been seen in Poland for 10 years [22]. This may probably be caused by the fact that fruit and vegetables are the most expensive foods. In the case of our respondents, who are beginning their career, and who often have to pay for their studies, it is an important obstacle on the way to their consumption. The problem of low consumption of fruit and vegetables is noted in the group of students in various countries $[1,11]$. Attempts are made to indicate various ways to increase the interest of young people in these products, and the most important are better prices, more availability, increase in varieties, readyto-eat packs [20]. Similar reasons may be obstacles for an increase in the consumption of complex carbohydrates. They definitely appear too seldom in the diets of students and less than half of students eat them often enough.

An even smaller number of respondents regularly eat dairy products. This is even more worrying as the percentages noted in the current study are lower than in the population of adult Poles, of whom $44 \%$ do not eat products of this type every day [22]. The dietary recommendations for healthy adults recognise the advantages of consumption of fermented milk and its products. Taking into account the fact that 5-40\% of inhabitants of Poland display intolerance of cow's milk protein $[8,16]$, this element of diet should be promoted and implemented in diets. In the studied group $27 \%$ follow this recommendation daily.

Information about health advantages of eating fish is generally available in the media and popular magazines. Sea fish are indicated as an extremely good source of unsaturated fatty acids (omega 3). Even though we see a growing trend in the consumption of fish in Poland [9, 15], fish is still not chosen by the Poles often enough - only $23 \%$ people declare eating fish a few times a week and $56 \%$ a few times a month [22]. In the declarations of the studied group of people we noted that almost half of them eat fish at least once a week, yet an equally large number of people do not eat enough fish. Even a higher percentage of fish consumption among students was noted by Duda in her study [6], where only $11 \%$ of students eat fish less often than a few times a 
week. This type of tendencies can be an effect of widespread information campaigns and better availability of the product in the market. This conclusion is also confirmed by other observations. The consumption of meat products, in particular the so-called red meat and animal fats in the studied group of people is not too high compared to the trends noted in the population of adult Poles. Only $12 \%$ of subjects consume products of this type every day, and more than $20 \%$ do so a few times a week, which is a highly expected behaviour. Similar, good trends are noted in other studies [6] which reveal the changes in students' preferences towards more frequent eating of poultry and the limitation of red meat consumption.

The study proposed to construct the Dietary Behaviour Index on the basis of 12 studied habits. Taking into account its correlations with individual behaviour, it can be stated that it allows for distinguishing people with a more or less healthy diet. In the analysis of the individual elements of food consumption structure, the percentage of people who follow the desirable model of dietary behaviour in the studied group of students is moderate and comparable to the percentage of people showing an unfavourable model of dietary behaviour (that is approx. 22\%).

\section{CONCLUSIONS}

The majority of the students, participating in the study, present a moderately beneficial model of dietary behaviour and almost one in four students follows the healthy eating style. Probably as a consequence the percentage of overweight and obese people is lower than in many countries of Western Europe or America.

Particularly worrying dietary mistakes, made by the students, are a low consumption of fruit and vegetables, fish and low-fat dairy products. Good trends were noted in terms of regularity of meals and the limited consumption of red meat.

The proposed Dietary Behaviour Index was the way to estimate the diets of the young people. The majority of participants follow a moderately beneficial model of behaviour.

Socio-demographic variables, which characterise the subjects, differentiated their dietary behaviour to some extent and the most important one is the field of study. Thus our suggestion is that the time of university studies may and should be used more intensively to promote a healthy lifestyle, in particular for students whose field of study is not related to health. 


\section{REFERENCES}

1. Anding J. D., Suminski R. R., Boss L. (2001). Dietary intake, body mass index, exercise, and alcohol: Are college women following the Dietary Guidelines for Americans? J Am Coll Heath, 49, 167-171.

2. Całyniuk B., Grochowska-Niedworok E., Białek A., Czech N., Kukielczak A. (2011). Piramida żywienia - wczoraj i dziś. Probl Hig Epidemiol, 92, 1, 20-24.

3. Capita R., Alonso-Calleja C. (2003). Intake of nutrients associates with an increased risk of cardiovascular disease in a Spanish population. International Journal of Food Sciences and Nutrition, 54, 57-75.

4. Colić Barić I., Satalić Z., Lukesić Z. (2003). Nutritive value of meals, dietary habits and nutritive status in Croatian university students according to gender. International Journal of Food Sciences and Nutrition, 54, 6, 473-484.

5. Ding E. L., Mozaffarian D. (2006). Optimal dietary habits for the prevention of stroke. Semin Neurol, 26, 1, 11-23.

6. Duda B. (2006). Nutrition and body mass assessment of extra mural students from the Medical Academy and the Academy of Physical Education and Sport in Gdańsk. Acta Medica Lituanica, 13, 1, 34-37.

7. Gawęcki J., Hryniewecki L. (2000). Żywienie człowieka. Podstawy nauki o żywieniu. PWN, Warszawa.

8. Heyman M. B. (2006). From The American Academy of Pediatrics: Lactose Intolerance in Infants, Children, and Adolescents. Pediatrics, 118, 3, 1279-1286

9. Honkonen P., Brunsø K. (2005). On the average European fish consumption is below recommended levels. The SEAFOOD plus project 2.1. printed from www.SEAFOODplus.org. Accessed on 15.04.2011

10. Hung H. C., Joshipura K. J., Jiang R., Hu F. B., Hunter D., Smith-Warner S. A., Colditz G. A., Rosner B., Spiegelman D., Wiolett W. C. (2004). Fruit and vegetable intake and risk of major chronic disease. J Natl Cancer Inst, 96, 21, 15771584.

11. Lowry R., Lee S. M., Mckenna M. L., Galuska D. A., Kann L. K. (2008). Weight Management and Fruit and Vegetable Intake Among US High School Students. J Sch Health, 78, 8, 417-24.

12. Manson J. E., Skerrett P. J., Greenland P., VanItallie T. B. (2004). The escalating pandemics of obesity and sedentary lifestyle. A call to action for clinicians. Archives of Internal Medicine, 164, 3, 249-258.

13. Nawyki żywieniowe i upodobania kulinarne Polaków. (2000) Komunikat z badań. CBOS, Warszawa.

14. Obesity: preventing and managing the global epidemic. (2000). Report of a WHO Consultation. WHO Technical Report Series 894. Geneva: World Health Organization

15. Seremak-Bulge J. (2010). Rynek i spożycie ryb w latach 2009-2010.: www.sprl.pl/doc/konf2010/rynek.pdf. Accessed on 15.04.2011 
16. Socha J., Książyk J., Flatz G., Flatz S. D. (1984). Prevalence of primary adult lactose malabsorption in Poland. Ann Hum Biol, 11, 311-316.

17. Taylor J. P., Mccarthy M. J., Herbert R. J., Smith P. B. (2009). A Comprehensive Profile Of Health Risk Behaviors Among Students At A Small Canadian University. College Student Journal, 43, 2, 255-267

18. US Department of Agriculture (2011). USDA's MyPlate. http://www.choosemyplate.gov/Accessed on 04.07.2012

19. US Department of Health and Human Services. US Department of Agriculture (2010). Dietary Guidelines for Americans. ( $7^{\text {th }}$ ed.) US Government Printing Office, Washington, DC, http://www.cnpp.usda.gov/Publications/

DietaryGuidelines/2010/PolicyDoc/PolicyDoc.pdf Accessed on 04.07.2012

20. Walker B. M., Schroeter C., Wolf M. M. (2009). An Examination of College Students' Produce Consumption and Purchasing Behavior: A Case Study in California. Journal of food distribution research, 40, 1, 180-186

21. Willett W. C, Stampfer M.J. (2003). Rebuilding the Food Pyramid. Scientific American, 288, 1, 64-71.

22. Zachowania i nawyki żywieniowe Polaków. (2010). Komunikat z badań. CBOS, Warszawa.

23. Złota Karta Prawidłowego Żywienia. (1997). Czynniki Ryzyka, 3-4.

\section{Correspondent author:}

Ida Laudanska-Krzeminska

Department of Health Education

University School of Physical Education

ul. Krolowej Jadwigi 27/39

61-871 Poznań, Poland

E-mail: idalk@poczta.fm 